agriTECH, 41 (2) 2021, 161-171

\title{
Production of Denatured Whey Protein Concentrate at Various pH from Wastewater of Cheese Industry
}

\author{
Robi Andoyo ${ }^{1 *}$, Anindya Rahmana Fitri ${ }^{1}$, Ratih Siswanina Putri ${ }^{1}$, Efri Mardawati ${ }^{1}$, \\ Bambang Nurhadi ${ }^{1}$, Nandi Sukri ${ }^{1}$, Rudi Saprudin Darwis ${ }^{2}$

\begin{abstract}
${ }^{1}$ Department of Food Industrial Technology, Universitas Padjadjaran, West Java, Indonesia Jalan Raya Bandung Sumedang KM 21, Jatinangor 40600 Sumedang, West Java, Indonesia ${ }^{2}$ Department of Social Welfare, Universitas Padjadjaran, West Java, Indonesia Jalan Raya Bandung Sumedang KM 21, Jatinangor 40600 Sumedang, West Java, Indonesia

*Corresponding author: Robi Andoyo, Email: r.andoyo@unpad.ac.id
\end{abstract}

Submission: April 15, 2020; Revision: May 18, 2020; Acceptance: June 8, 2020

\begin{abstract}
Wastewater produced from cheese industry is rich in biological component such as whey protein, fat and lactose. Whey protein is the residual liquid of cheese making process with a high protein efficiency ratio. The wastewater source used in this study was whey liquid from cheese processing industry located at West Java, Indonesia. Conversion of soluble whey protein into whey protein microparticle is required to produce food with nutritional value that can be adjusted to the needs of the specific target with high digestibility and palatability. Whey protein was collected by separation technique through heat treatment at specific condition. This was done by changing the heat treatment condition and $\mathrm{pH}$ of the samples. Changing the $\mathrm{pH}$ of the samples before heat treatment affect the ionic strength of the whey protein hence, altering the properties of the concentrate. This study aims to produce whey protein concentrate heated at various $\mathrm{pH}$ level and to observe physicochemical and functional properties of the concentrates. The method used in this research was a descriptive method conducted on three treatments and two replications namely whey protein concentrate production in a $\mathrm{pH}$ condition $6.4 ; 6.65$; and 7.0. The parameters observed were physicochemical and functional properties. Furthermore, the result showed that there were decrease in protein content, along with the increasing $\mathrm{pH}$ before heat treatment. Microstructure image (SEM) showed a finer particles with the increasing $\mathrm{pH}$. Meanwhile, solubility of the rehydrated samples tends to increase along with the increasing $\mathrm{pH}$. The measurement of functional properties of the samples showed that denatured whey protein produced at different $\mathrm{pH}$ before heat treatment have different water holding capacity and a tendency to form bonds between protein particles thereby increasing the viscosity value. These physicochemical and functional properties were suitable for denatured whey protein to be used as a texture controller in whey protein based-food production.
\end{abstract}

Keywords: Cheese industry; pH modification; wastewater; whey protein concentrate 


\section{INTRODUCTIONS}

Wastewater produced from cheese industry is rich in biological component such as fat, protein, lactose, minerals, enzymes, phospholipids, and several types of vitamins (Saleh, 2004). Majority of the milk protein consists of $80 \%$ casein while the rest is whey protein, with the largest constituent consisting of a-lactalbumin and $\beta$-lactoglobulin (Lucey, 2004).

Whey is one of the dairy products, made from milk that has been separated from fat and casein (Chandan et al., 2008). Separation of casein and whey in milk can be done in several ways, including the addition of the enzyme rennet or renneting. Casein that has been separated that has been separated and coagulated is called curd, while the non-separate parts are in liquid form and are called sweet whey liquid. In addition, sweet whey liquid still has other nutrients such as carbohydrates which are mostly in the form of lactose, fat, and minerals. Fat content in sweet whey liquid can be removed through a separation process so that defatted whey can be processed further into whey protein concentrate (Chandan et al., 2008). Whey protein products in form of powder in the market consist of several types, namely whey protein concentrate, whey protein isolate, whey protein powder, and others. Whey protein concentrate is one of the dairy products produced from the byproducts of making cheese, commonly called sweet/acid whey liquid or whey cheese. According to the 2004 quality standard of the U. S. Dairy Export Council, whey protein concentrate circulating on the market contains about $34-80 \%$ protein. Meanwhile, whey protein isolate has a total protein content of $92 \%$ (Smith, 2008).

The quality of protein in whey is higher compared to casein due to the essential amino acids content, including valine, trytophan, threonine, lysine, leucine, isoleucine, and histidine (Onwulata, C.I and P. J. Huth, 2008; Andoyo et al., 2018). Furthermore, addition of whey protein into food formulation had attracted great attention. The purpose of adding whey protein into various food products formula is not only for increasing the protein content of the products, but also may affect the physical and functional properties such as high solubility, high water holding capacity, and gel forming capability characteristics (Khairunnisa, S et al., 2018). The use of whey protein in powder form is considered more practical and have longer shelf life than its liquid form (Smith, 2008).

Whey natural protein is not a byproduct of cheese processing, but the results of filtering milk using membrane filtration. Whey natural protein contains protein in a non-denatured state because excessive heat is not applied during the manufacturing process (heating is only done during the pasteurization process of milk). Non-denatured proteins have different functional properties than denatured proteins due to differences in the molecular structure. Native whey protein has the same function as other proteins in food, namely as an emulsifier, gelation agent, foam formation agent, changing the solubility of substances and the viscosity of a fluid, as well as increasing water holding capacity (Morand et al, 2011). Native whey protein has high hydrophilic properties, indicating it's ability to easily dissolve in water and its solubility reaching $99 \%$ (Smith, 2008). Generally, natural whey protein is used as a highprotein beverage fortification ingredient. Denatured whey protein has a lower solubility as compared to the native ones (Morand et al., 2011). Therefore, it is more suitable as a fortification material for high protein solid food products (Awwaly et al., 2010).

The modification process in whey protein concentrate making can change the structure of the protein so that its functional properties change. One modification process that can be done is heating at 90 ${ }^{\circ} \mathrm{C}$ for 60 minutes. Heating is a technique to separate whey protein from sweet whey liquid. This heating process leads to protein denaturation and under certain conditions $(\mathrm{pH}$, protein concentration, temperature and heating time, and salt content) might form aggregates so that the protein becomes insoluble in water (Guyomarc'h et al., 2014). Separation of protein aggregates can be carried out through centrifugation, whey protein is then dried in a vacuum oven to prevent the effects of excessive heat which can change the functional properties. Moreover, whey protein is sensitive to heat so that the drying temperature used is $50{ }^{\circ} \mathrm{C}$ under vacuum (Sitindaon, 2017).

Protein denaturation is a change or modification of secondary, tertiary, and quaternary structures of protein molecules, without the breakdown of covalent bonds. One of the causes of denaturation in whey protein is the continuous application of heat above the denaturing temperature. In addition, changes in $\mathrm{pH}$ can also affect the process of denaturation (Winarno, 1992). Protein has a charge whose value is influenced by $\mathrm{pH}$, at its isoelectric $\mathrm{pH}(\mathrm{pI})$, the charge of the protein is 0 (not charged). When the $\mathrm{pH}$ is above the isoelectric point, the charge is negative, whereas when the $\mathrm{pH}$ is below the isoelectric point, the charge is positive. The existence of this charge results in interactions between proteins. When it is at the pI point, there is an interaction pulling the protein molecules hence, when it is warmed up, a large aggregate is formed (Andoyo et al., 2018; Guyomarc'h et al., 2014). When the dominant protein is negatively or positively dominant, there is a repulsive force between 
protein molecules, hence, when overheated, it will form small aggregates (Guyomarc'h et al., 2014). The combination of heating and $\mathrm{pH}$ at the range of 6.3 to 7.3 will ultimately affect the physicochemical characteristics and functional properties of denatured whey protein concentrate produced through the formation of covalently bound heat-induced complexes of protein (Donato, L, Dalgleish D.G., 2006; Morand et al., 2011). These physicochemical characteristics include solubility, viscosity, color, moisture content, protein content, and lactose content while functional characteristics include gel strength, viscosity, and whey drainage (Morand et al., 2011). The functional properties of whey protein can be evaluated through the formation of gel from denatured whey protein. Based on the description above, in the current study, pH modification will be applied in the manufacture of denatured whey protein concentrate by vacuum drying and evaluating it physicochemical characteristics and functionality of the resulting whey protein concentrate.

\section{MATERIALS AND METHODS}

\section{Materials}

The materials used were whey liquid collected from Koperasi Peternak Susu Bandung Selatan (KPBS) Pangalengan, West Java, microbial rennet (Rhyzomucormiehel) (+QSO), and distilled water. The chemicals used were $\mathrm{NaN}_{3}, 5 \% \mathrm{HCl}, 5 \% \mathrm{NaOH}, \mathrm{HgO}$, $\mathrm{K}_{2} \mathrm{SO}_{4}, \mathrm{H}_{2} \mathrm{SO}_{4}$, protein indicator, aquadest, $5 \% \mathrm{ZnSO}_{4}$, $4.5 \% \mathrm{Ba}(\mathrm{OH})_{2}, 1 \%$ Phenol, $5 \% \mathrm{NaOH}$, Picric Acid $1 \%$, Na-disulfite $1 \%$, and glucono- $\delta$-lactone (GDL). All chemicals used in this research were analytical grade.

The instruments and tools used in this study were cheese vat (armfield), cream separator (armfield), stirrer (Thermo Scientific), pH meter (Lutron PH 208), double jacket batch pasteurizer (Armfield), data logger (IR Instruments), centrifuge, vacuum oven, tyler sieve, SEM (JSM 6360 LA), spectrophotometer CM-5 (Minolta), rotational viscometer (Rypa), texture analyzer (Stable microsystem) and zeta sizer (Shimadzu).

\section{Methods}

The properties observed in this research were physicochemical and functional properties. The method used was descriptive method (Explanatory Research). The analysis was performed on 3 treatments with 2 replications, the data was presented in the form of bar charts and figure. The significance of the data was analyzed using t-test $(p<0,05)$. The treatments in this study were as follow:
$\mathrm{A} 1=$ Production of Whey Protein Concentrate at $\mathrm{pH} 6.4$

$\mathrm{A} 2$ = Production of Whey Protein Concentrate at $\mathrm{pH}$ 6.65

$\mathrm{A} 3=$ Production of Whey Protein Concentrate at $\mathrm{pH} 7.0$

\section{Whey Protein Production}

Whey protein was produced by following a set of process which divided into two parts, firstly separating sweet whey liquid from fresh milk and secondly producing whey protein powder from sweet whey liquid as presented in diagram process (Figure 1).

Milk was conditioned by its $\mathrm{pH}$ at certain points, namely $6.4 ; 6.65$; and 7.0 . To reduce $\mathrm{pH}$ to 6.4 was done by adding $5 \% \mathrm{HCl}$ solution to a certain volume until it reaches $\mathrm{pH} 6.4$, while increasing $\mathrm{pH}$ to 7.0 was done by adding $5 \%$ volume until it reaches $\mathrm{pH} 7$.

\section{Curd formation}

Sweet whey liquid at adjusted $\mathrm{pH}$ conditions was produced in the cheese industry of Koperasi Peternak Susu Bandung Selatan (KPBS) Pangalengan, West Java, Indonesia. The following process was performed in the cheese plan, fresh milk was heated to a temperature of $35^{\circ} \mathrm{C}$ in cheese vat, the temperature was maintained while rennet was added for coagulating the milk. Rennet is an enzyme that functions to coagulate milk protein to form fresh milk, $0.02 \mathrm{~g}$ was added for every $1 \mathrm{~L}$ of milk. Moreover, $\mathrm{NaN}_{3}$ was also added at this stage to inhibit bacterial growth during subsequent processing and product storage, $0.2 \mathrm{~g}$ was added for every $1 \mathrm{~L}$ of milk. Afterwards, cheese vat was closed and left for 1 hour until a milk curd was formed that resembles a jelly mass. Complete coagulation was marked by pressing the finger, stirring rod, or thermometer in curd. When a sharp and flat hemisphere occurs, the curd is ready to be cut.The curd was cut using knife into smaller pieces, then, Whey was separated from curd by filtration.

\section{Separation of whey cream (defatting) from sweet whey}

Whey liquid that has been separated from curd still contains milk fat. Separation of milk fat using a cream separator. Whey liquid was first heated to $55^{\circ} \mathrm{C}$, then put in a cream separator. The results of this separation consist of two phases, namely whey cream and defatted whey. Whey then heated in a double jacket batch pasteurizer at $90{ }^{\circ} \mathrm{C}$ for 60 minutes. Heating aimed to form a whey protein aggregate characterized by changes in turbidity after the heating process. After heating, it formed a non-soluble solids, namely the whey protein component. Centrifugation was performed to separate non-dissolved solids into deposits and supernatants. 


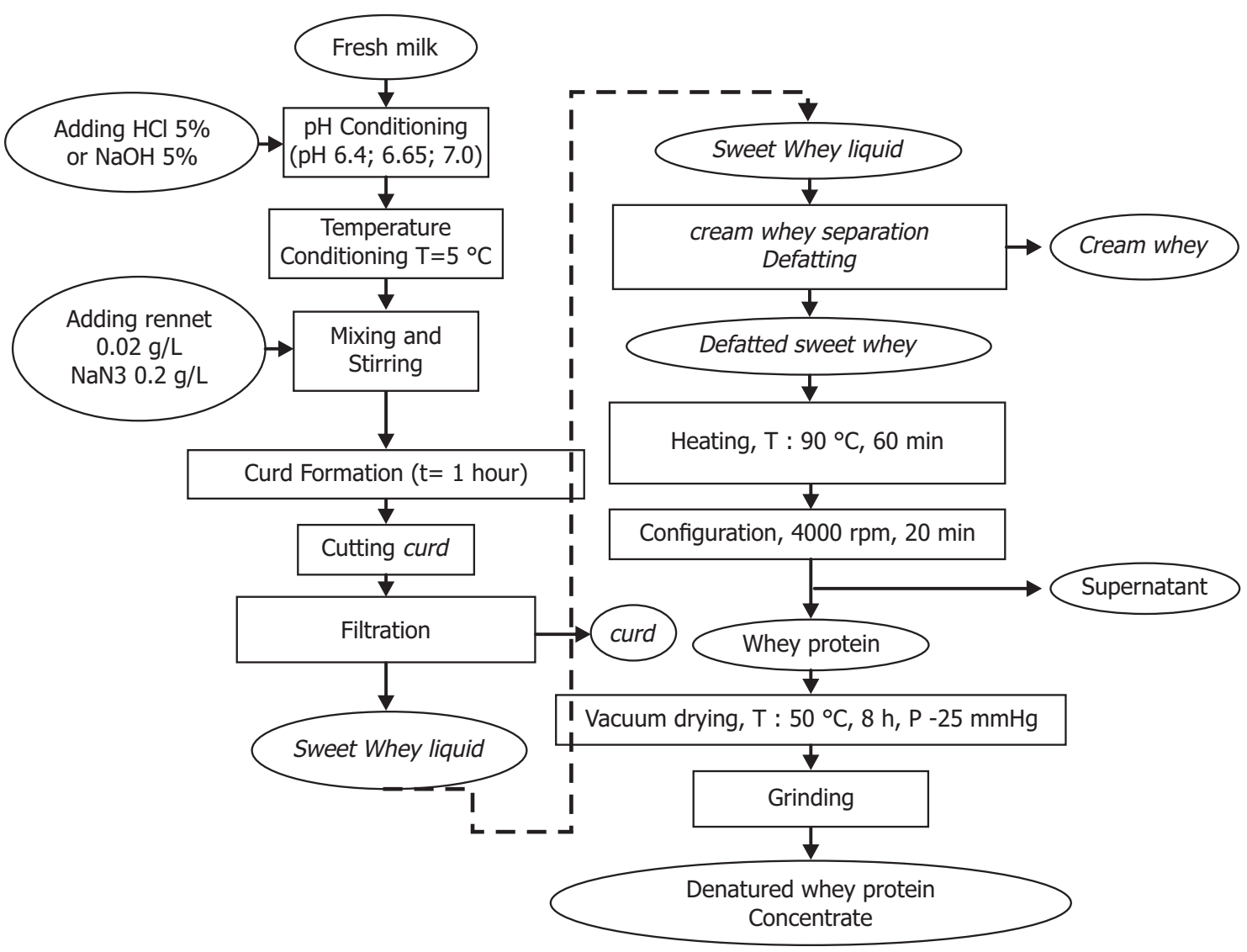

Figure 1. Process diagram of separating whey from fresh milk (Putri, 2016)

\section{Vacuum drying}

The whey protein deposits were dried using a vacuum dryer at $50{ }^{\circ} \mathrm{C}$ for approximately 8 hours. The thickness of the whey protein solids per pan was uniform. The drying process produced whey protein in the form of flakes. The dried whey protein produced was uniformed using a grinder, for 2.5 minutes every $50 \pm$ $3 \mathrm{~g}$ to produce whey protein concentrate powder. Whey concentrate protein was put into an airtight bottle for further analysis. Parameter observed at this stage were protein, solubility and microstructure (SEM). Protein content was measured by Kjeldahl method (conversion factor 6.38), solubility was measured by the following Equation 1.

Solubility $(\%)=\frac{W_{\text {dried supernatant }}}{W_{\text {sampel }}} \times 100 \%$

(Equation 1)

\section{Whey Protein Gels Production to Evaluate Functional Properties}

Whey protein powder that had been produced was analyzed for its physicochemical properties then analyzed for its functional properties. Functional properties were evaluated by producing gels. Protein gels being composed of three-dimensional matrices or networks of intertwined, partially-associated polypeptides in which water is entrapped. Protein gels is formed from these two stages, firstly the denaturation and secondly is the association to form network. The formation of protein gels used in the current study can be seen in a process diagram presented in Figure 2.

\section{Production of whey protein solution}

Whey protein powder produced at $\mathrm{pH} 6.4, \mathrm{pH}$ 6.65 , and $\mathrm{pH} 7.0$ was dissolved in skim milk made with a total protein concentration of $5 \%$ or $50 \mathrm{~g} / \mathrm{kg}$ which is the concentration needed to form the gel. The ratio of protein concentration between whey protein powder and skim milk is 1:4. The protein solution that has been obtained was placed on the hotplate and stirred using a magnetic stirrer at $65^{\circ} \mathrm{C}$ for 30 minutes. Stirring and heating at $65^{\circ} \mathrm{C}$ for 30 minutes is done to denature proteins thereby forming protein aggregates, which is the initial stage in the gel formation process. Control samples were evaluated by using pure skim milk with similar procedure as treated samples. 


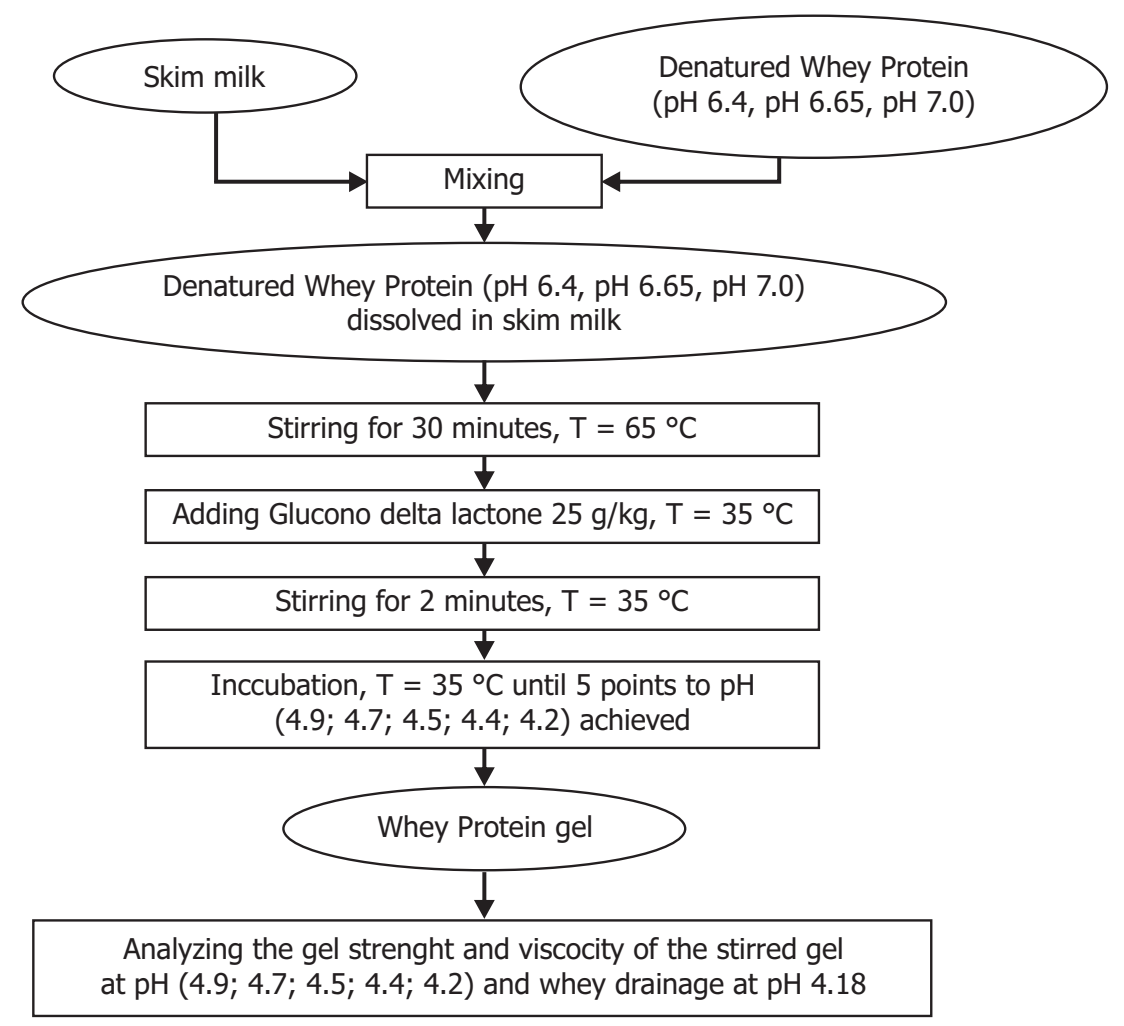

Figure 2. Process diagram of gel whey protein concentrate production

(Andoyo et al., 2014)

\section{Temperature conditioning and acidification}

The solution was stirred and heated for 30 minutes then cooled or conditioned to $35^{\circ} \mathrm{C}$. This temperature conditioning aims to get the optimal temperature for Glucono- $\delta$-lactone (GDL) acidification, which is an acid added to a protein solution. The addition of GDL aims to gradually reduce the $\mathrm{pH}$ of protein solutions in gel formation. GDL was added to a protein solution at 35 ${ }^{\circ} \mathrm{C}$ and stirred for 2 minutes using a magnetic stirrer. This stirring aims to dissolve GDL in a protein solution. Solutions that have been added by GDL are then placed into a plastic tube. Then, incubation in an oven that was set to temperature of $35^{\circ} \mathrm{C}$. Incubation was carried out so that the optimal temperature of GDL was maintained at $35^{\circ} \mathrm{C}, \mathrm{pH}$ reduction process carried out for 4 hours. One plastic tube containing a sample was provided for $\mathrm{pH}$ measurement using a $\mathrm{pH}$ meter. When the $\mathrm{pH}$ of the control reaches $5 \mathrm{pH}$ points $4.9 ; 4.7 ; 4.5 ; 4.4 ; 4.2$, samples were taken and stored in a refrigerator at a temperature of $<5^{\circ} \mathrm{C}$ then observed the gel strength by using texture analyzer, and viscosity of stirred gel 5 $\mathrm{pH}$ points using rotational viscometer and carried out measurements of gel whey drainage at $\mathrm{pH} 4.2$ or after gel has a self-standing structure follows the procedure of Andoyo et al. (2014).

\section{RESULTS AND DISCUSSION}

\section{Physicochemical Properties}

\section{Protein content}

Figure 3 shows that the higher the $\mathrm{pH}$ of fresh milk used for the production of denatured whey protein concentrate, the lower the protein content achieved in the powder stage ( $t$ test, $\mathrm{p}<0.05$ ).

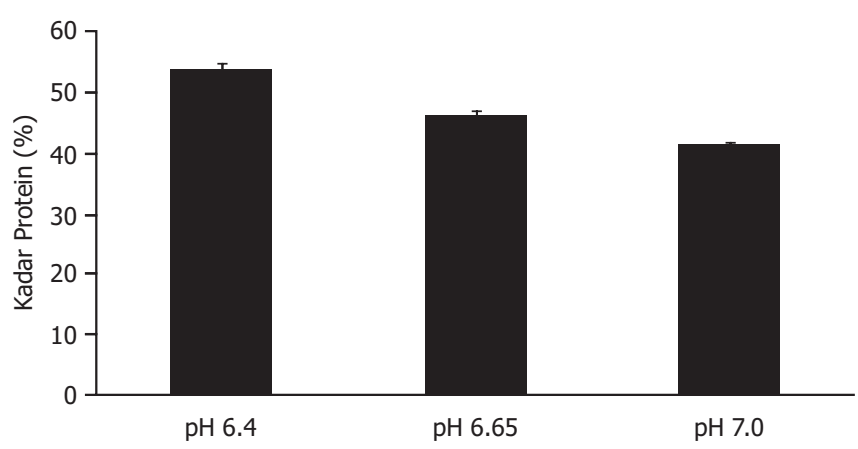

Figure 3. The protein content of denatured whey protein concentrate produced at certain $\mathrm{pH}$ Level. Vertical bar above the histogram indicate the standar deviation. 
Commercial whey contain protein ranging from 34 to $80 \%$. The curd formation in renneting process was one of the factor that determines the protein content in denatured whey protein concentrate. During the renneting process, rennet, which coagulates casein, was added to fresh milk whose $\mathrm{pH}$ has been conditioned. Rennet was able to coagulate milk casein in the $\mathrm{pH}$ range 5.8-6.6 (Awwaly et al., 2008). This shows that the enzyme failed to function optimally at high $\mathrm{pH}$, in this case the casein did not fully coagulate. Uncoagulated casein affects the production of denatured whey protein concentrate and affects the final product. Another factor that influences protein content was the amount of protein aggregate that was formed during heating at $90{ }^{\circ} \mathrm{C}$ for 60 minutes. The closer the $\mathrm{pH}$ of whey protein to $\mathrm{pI}$ (isoelectric $\mathrm{pH}$ ), the more whey protein aggregates were formed after heating. Whey protein aggregates can be formed as a result of interactions between protein molecules. The interaction between whey protein molecules causes a decrease in the solubility of whey protein (Dissayanake, 2011). The more whey protein molecules that are less soluble in water, the more protein molecules that can be separated when centrifuged, so the protein content of whey protein concentrate tend to increase. The size of the aggregate (Figure 5) of whey protein particles can also affect protein levels in denatured whey protein concentrate. The process of forming whey protein aggregates when heated above the isoelectric point produced small aggregates. This size was related to the molecular weight, the smaller the size, the lower the molecular weight (Andoyo et al., 2018). Low molecular weight of protein particles were not able to separate into sediments during sentrifugation, thereby resulting in a lower protein content of the final product.

\section{Solubility}

Protein is expected to have high solubility properties. This is to support good emulsion formation, froth, gelation and whipping properties. Low solubility properties will indicate poor functional properties. Protein solubility is associated with hydrophobic parts (proteins) and hydrophilic parts (protein-solvents) (Pelegrine and Gasparetto, 2004).

Figure 4 shows that the the higher the $\mathrm{pH}$ of fresh milk used to produce denatured whey protein concentrate, the higher the solubility ( $t$ test, $p$ $<0.05$ ). The surface hydrophobicity of the aggregates constitutes an important parameter to control their solubility and reactivity. The solubility of denatured protein was decreased due to the exposed inner layer of hydrophobic protein molecules, while the hydrophilic as outer part was folded inward (Guyomarc'h, F., 2014).

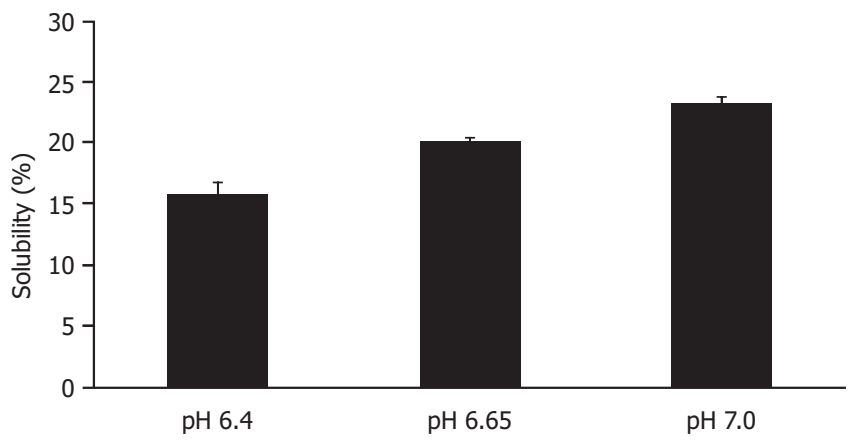

Figure 4. The solubility of denatured WPC produced at certain pH level. Vertical bar above the histogram indicate the standar deviation.

Folding or reversal occurs especially when the protein solution has approached the $\mathrm{pI}$ (isoelectric $\mathrm{pH}$ ), in this case the lower the $\mathrm{pH}$, the closer to the whey protein $\mathrm{pI}$, which was pH 4.6 (Winarno, 1992). A high solubility was occurred because the hydrophilic surface so it tends to bind water molecules. The average pI of the whey protein produced in this study was determined by zeta sizer and the isoelectric $\mathrm{pH}$ was 4.13 . This confirmed that heat treatment of whey protein at the $\mathrm{pH}$ of 6.4 has the lowest solubility, due to the nearest $\mathrm{pH}$ to $\mathrm{pI}$.

The whey drainage of protein molecules (Figure $6 B)$ also influences their solubility. The ability of proteins to bind water was caused by the presence of hydrophilic and charged groups. One of the main factors that affect the water binding capacity of protein was the $\mathrm{pH}$. When the negative and positive charges of the protein are the same (reaching the isoelectric point) the interaction between proteins reaches the maximum, while the water binding capacity decreases. Interaction between proteins decreases when protein was increasingly charged. When this happens, the interaction between water and protein will increase which means the water holding capacity also increases (Andarwulan et al., 2011). Solubility of the treated samples at pH 7.0 has the highest solubility among the other due to negatively charged solution. When the protein molecule is in a non-denatured state, the hydrophilic group was on the surface so that it can bind water easily. When the protein molecule is in a denatured state, a structural change occurs which results in the hydrophilic group being on the inside while the hydrophobic group is on the outside making it difficult to bind water. The ability of the water binding capacity will affect solubility because the more protein molecules that bind to water, the more these proteins dissolve in water (soluble) (Andoyo et al., 2014).

The size of the denatured whey protein concentrate particles as shown in the Figure 5 decreases as the 
(a)
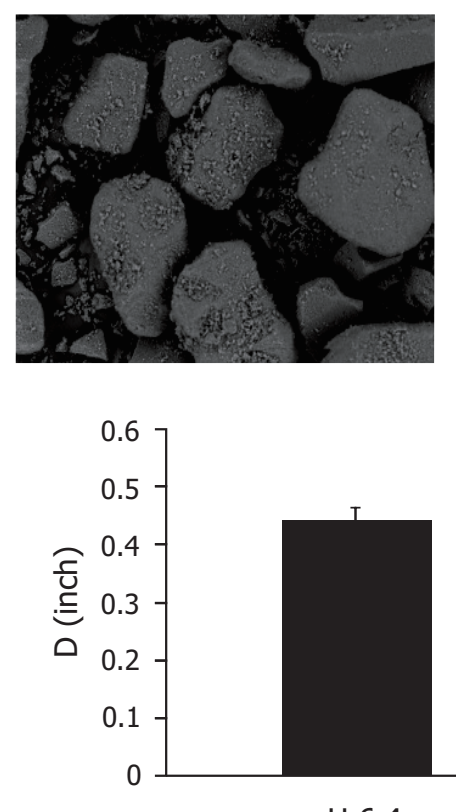

pH 6.4 (b)

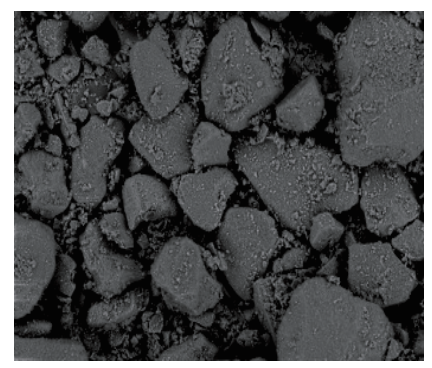

(c)

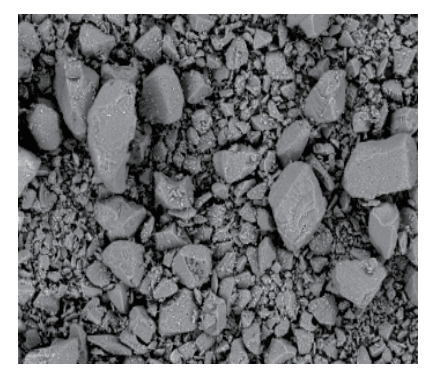

Figure 5. Microstructure and average diameter of denatured whey protein concentrate particles (a) pH 6.4; (b) pH 6.65; (c) pH 7.0. Vertical bar above the histogram indicate the standar deviation.

increase in $\mathrm{pH}$ of fresh milk also influences its solubility. The smaller the particle size, the greater the surface area, allowing more water to interact with the particles. Solubility properties are also related to the texture of high protein solid food products formulated by denatured whey protein concentrate. The nature of high solubility can cause the texture of solid food products to become hard so it is more suitable to be formulated in high protein drinks.

\section{Micro structure}

Microstructure of whey protein was observed using Scanning Electron Microscope (SEM) and average particle size was determined by sieve test (Figure 5). The principle of SEM is to describe the surface of an object or material with a beam of electron reflected with high energy. Denatured whey protein concentrate particles observed microscopically with a magnification of $150 \times$ can be seen in Figure 5 that shows the size of denatured whey protein concentrate particles made in various $\mathrm{pH}$ conditions tends to decrease along with the increase in milk pH. Figure 5 shows that the the higher the $\mathrm{pH}$ of fresh milk used to produce denatured whey protein concentrate significantly reduce the average size of protein particles ( $t$ test, $p<0.05$ ). The picture also shows that the increase of the $\mathrm{pH}$ of milk increases the porosity of whey protein concentrate. The possible reason for this result because the porosity of the powder is related to the size of the particles, hence, the smaller the particle size (Figure 5), the more number of particles at the same volume thereby resulting in more connectivity between particles that indicate porousity.

Proteins in their natural state are present in a multiple form. These particles are larger in size as a result of proteins interaction (Dissayanake, 2011). The average diameter of particles can be affected by the interaction between casein, derived from casein which is not coagulated during renneting, and whey protein. (Anema and Li, 2003) stated that the more casein that interacts with denatured whey protein, the greater the particle size. The interaction between casein and denatured whey protein is affected by $\mathrm{pH}$, where the higher the $\mathrm{pH}$, the less interaction between the two, thus results a smaller particle size.

The process of denaturation and the formation of whey protein particles is very dependent on $\mathrm{pH}$ because it is affected by its electrostatic charge. When the heating process close to pI, whey protein has a 0 net charge and leads to an increase in attractive forces on proteins so that a large protein particles are formed. In contrast, when the $\mathrm{pH}$ is far from pI, whey protein is dominated by negative charge and the repulsive force thereby resulting in a smaller protein particles (Guyomarc' $h$, F et al., 2014; Andoyo et al., 2018). The microstructure 
and particle size measurements as shown in Figure 5 confirmed that the protein particles produced at the $\mathrm{pH}$ close to $\mathrm{pI}$ have a larger size than protein particles produced at the $\mathrm{pH}$ far from the $\mathrm{pI}$ of whey protein. The average $\mathrm{pI}$ of whey protein produced in this study was determined by zeta sizer and the isoelectric $\mathrm{pH}$ was 4.13.

\section{Functional Properties}

\section{Gel strength}

Figure $6 \mathrm{~A}$ showed the increase in gel strength from the starting point of acidification at the $\mathrm{pH}$ of 4.9 to $\mathrm{pH}$ 4.7 then the gel strength decreases when it leaves $\mathrm{pH}$ 4.7 to $\mathrm{pH} 4.2$. This is related to the balance of protein charge in the gel system. Protein has an isoelectric point which is a state in which the protein does not have the difference in charge or the amount of positive charge and the same negative charge (Hart et al., 2003). When the $\mathrm{pH}$ of protein is above the isoelectric point (pI), the protein charge is dominated by a negative charge whereas when the protein $\mathrm{pH}$ below the $\mathrm{pI}$ the charge is dominated by positive charge. This causes the repulsion of electrostatic between negatively charged particles and between positively charged particles so that the interactions that occur above and below the pI are interactions between proteins and water. During the process of acidification the $\mathrm{pH}$ of the whey protein decreases to the isoelectric point and then continues to decrease until it passes through the pI and stops the process at the point of pH 4.2 (Morand et al, 2011).

When the $\mathrm{pH}$ of whey protein gel decrease from 4.9 to 4.7 , it approached the $\mathrm{PI}$ (4.13). When the protein $\mathrm{pH}$ is near pI, the electrostatic repulsion is lower, allowing better hydrophobic interactions and resulting in increasingly hard gel and decreased syneresis
(Lucey, 2004). When it is at the isoelectric point, the interaction that tends to occur is the interaction of the proteins that build up the network because the positive charge and the negative charge of the protein at the isoelectric point have a zero difference so there is no electrostatic repulsion interaction (McSweeney and O'Mahony, 2016). The protein-protein interactions that build up this network cause gel strength to increase. This phenomenon was also observed from $\mathrm{pH} 4.9$ to 4.7 in Figure 6 for all treated samples. When reaching pI there is also the formation of disulfide bonds which can increase the molecular weight of aggregates formed during the gelation process and stabilize the network along with the increase in gel strength (Alting et al., 2004). When leaving $\mathrm{pH} 4.7$ the $\mathrm{pH}$ whey protein gel strength decreases steadily to $\mathrm{pH} 4.2$ because below the isoelectric point the protein charge is dominated by a positive charge which allows electrostatic repulsion so that protein-protein interactions tend not to occur and decrease the strength of the gel. The range of $\mathrm{pH}$ of the samples before heat treatment used in the current study ranging from 6.4 to 7 , but changes in gel strength during acidification can still be seen. This results confirmed that the formation of further protein network through the formation of disulfide bonds was also observed in all treated samples during acid gelation as indicated the change of gel strength value along acidification.

The trend of gel strength obtained in this study was consistent with several previous studies. The gel strength increased along with a decrease in $\mathrm{pH}$ to around $\mathrm{pH} 4.71$ and a decrease in the strength of the gel to $\mathrm{pH} 4.46$ and continued to $\mathrm{pH} 4.18$ (Situmorang, 2016). Research conducted by Purnama, 2016 also showed that there was an increase in gel strength from $\mathrm{pH} 4.98$ to $\mathrm{pH}$ 4.58 then the strength of the gel decreased again when $\mathrm{pH}$ left 4.58 to 4.18 on the samples treated at different mineral concentrations. Decreasing $\mathrm{pH}$ will increase gel
A

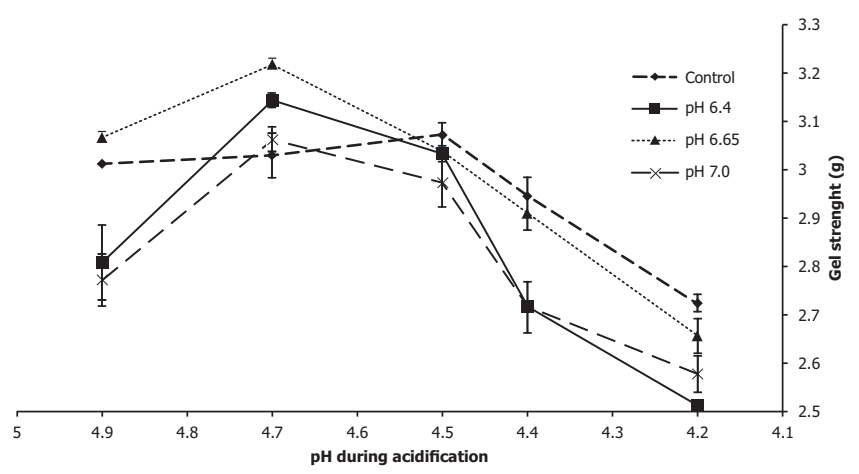

B

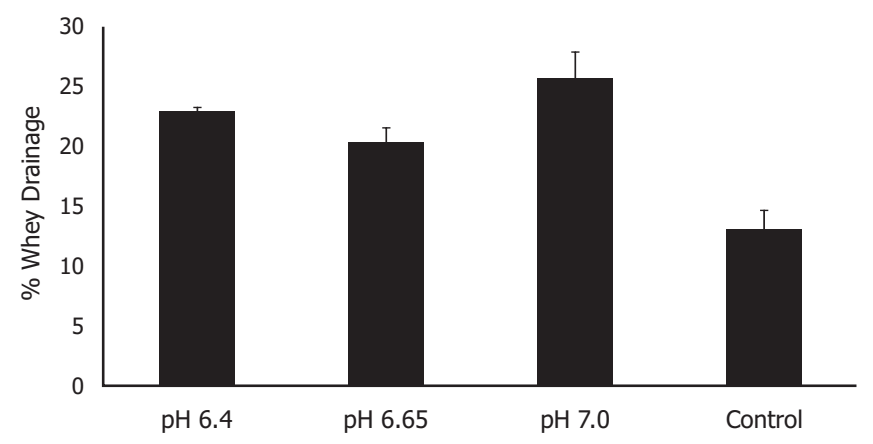

Figure 6. (A) Gel strength of denatured WPC during acidification, (B) Whey drainage of denatured WPC observed at $\mathrm{pH}$ 4.2. Vertical bars indicate the standar deviation 
strength to a certain $\mathrm{pH}$ then maximum gel strength occurs at $4.7 \mathrm{pH}$ and again decreases continuously to $\mathrm{pH} 3.5$ for samples treated at $\mathrm{pH} 7$ before heating and at varied mineral concentrations (Ju and Kilara, 1998).

The highest gel strength obtained at the $\mathrm{pH}$ point was thought to be the isoelectric $\mathrm{pH}$ because at this point the protein charge is in a neutral condition so that the force that occurs is the attractive force between the protein molecules which will bind to each other and form a strong structure. The $\mathrm{pH}$ point at the highest gel strength was thought to be an isoelectric point and several previous studies were achieved at different $\mathrm{pH}$ ranging from $\mathrm{pH} 4.5$ to 4.7 (Pelegrine and Gasparetto, 2005 and Morand et al., 2012). Factors that influence these differences include the purity of whey protein. When several types of protein are in a system, the pI from whey protein will change. (Morand et al., 2011) conducted a study that added $\mathrm{k}-\mathrm{CN}$ before heating into pure whey protein aggregates that had $4.7 \mathrm{pI}$. After heating, the pure aggregate whey protein $\mathrm{pI}$ decreased to 4.3. This decrease was caused by the difference in whey protein $\mathrm{pI}$ and $\mathrm{k}-\mathrm{CN}$ which were 4.7 and 4.0.

Whey protein gel samples $\mathrm{pH} 6.65$ showed the highest gel strength. This can be related to whey drainage and the ability of whey protein to hold water in the system (Figure 6B). Whey protein gel samples $\mathrm{pH} 6.65$ in this study showed the lowest whey drainage which means that it also has the highest WHC (Water Holding Capacity) value. This shows that the great ability of whey protein gel $\mathrm{pH} 6.65$ in trapping water so that most of the water from the solvent is trapped in the gel system. The ability of the gel to trap water is what is likely to affect the strength of the gel produced.

The three types of whey protein gel samples have lower gel strength than the control gel. This shows that whey protein has functional characteristics as a structure breaker as compared with control gel. The role as a structure breaker in the food system means that it can reduce the hardness of the material (Situmorang, 2016). Whey protein which was modified by conditioning the $\mathrm{pH}$ of milk during the production process, acts as a structure breakerand it was not expected to significantly change the food texture when added in high concentrations.

\section{Viscosity of stirred gel}

Viscosity measurement was performed to determine the functional characteristics of denatured whey protein produced using milk which is conditioned into several pH conditions. Based on (Bourne, 2002) and (Susanto and Yuwono, 2001) viscosity is defined as the internal resistance of the flow of liquid caused by the random motion of the molecule of the liquid.

Figure 7 showed that the trend in gel samples made from whey protein and control gel samples made from skim milk was increased in viscosity along with decreasing $\mathrm{pH}$ during the acidification process. The highest viscosity occurs in the acidification process from

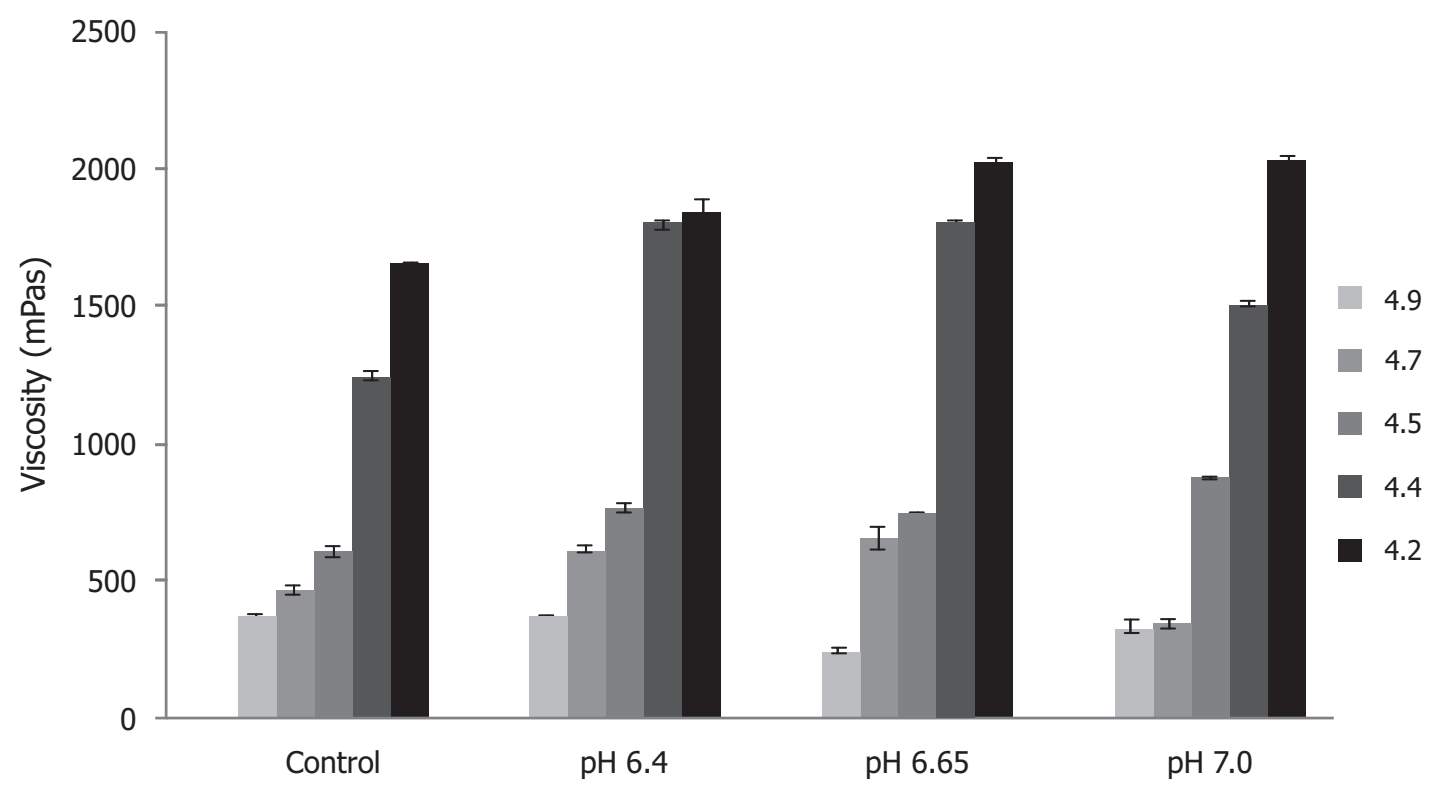

Gel Whey Protein Concentrate produced at some $\mathrm{pH}$ levels

Figure 7. Gel viscosity of denatured WPC produced at some pH level (Vertical bars indicate the standar deviation) 
the point of $\mathrm{pH} 4.5$ to $\mathrm{pH} 4.2$. When the $\mathrm{pH} 4.5$, it was thought that whey protein approaching the isoelectric point. Meanwhile, Figure 6A showed that at the $\mathrm{pH}$ of 4.7 the whey protein gel has the highest gel strengthwhich is also thought to be approaching the isoelectric point. The average isoelectric point of the denatured whey protein used in this research was 4.35. This isoelectric state allows proteins to interact with other protein molecules compared to water molecules because at the isoelectric point the negative charge and the positive charge of the protein are in the same amount so that the interaction between molecules occurs. The number of interactions between protein molecules in forming aggregates causes a decrease in water binding capacity in the sample (Sajedi et al., 2014).

The data in Figure 7 showed that increasing the $\mathrm{pH}$ of fresh milk to $\mathrm{pH} 7.0$ before heataing caused the lower viscosity of the gel obtained at least until $\mathrm{pH} 4.4$ during acidification. The further away from the isoelectric point the dominant protein charge was the negative charge so that the force that tends to occur was repulsion between protein molecules. Protein molecules interact with water molecules so that the resulting viscosity was low. This results also attributed to the size of whey protein particles. and also supported by the higher solubility value of whey protein along with the increase in milk pH. Small particle size has a higher surface area / contact area as compared to larger particles. The high surface area allows for more hydrophilic sides in whey protein to contact and binds to water to produce a low viscosity value.

The control gel in Figure 7 showed lower viscosity at almost all $\mathrm{pH}$ points compared to whey protein gel. Protein in skim milk is in a native state different from protein in whey protein which has undergone a denaturation process in the production process. Native proteins have high solubility in water so they do not cause clumping or deposition in the food system. This high solubility in water is caused by the amount of surface which is hydrophilic so that the interaction that tends to occur is the interaction between protein and water (Walstra et al., 2006). This tendency of protein to interact with water causes the viscosity of the control gel made from skim milk to be lower than the viscosity of the whey protein gel.

Gel viscosity and gel strength were thought to be correlated and the results thought to be always in-lined between these properties as long as both parameters were analyzed the sample at the same states. In fact, as oberved in this study both properties did not show in-line results. For an example, at $\mathrm{pH}$ of 4.2 the gel has the lowest gel strength but has the highest viscocsity. Factor that may affect these conflicting results was the viscoelastic properties of the gel that measured by using two different instruments e.g viscometer and texture analyzer. Viscoelastic materials such as gels supposed to be measured by using small deformation oscilative rheometer to identify both solid and liquid properties of the gel. In the current study, gels strength were measured by texture analyzer in solid form, while the viscosity of the gels were observed by using viscometer after the gels were stirred for 1 minute before measurement. Therefore, particle rearrangement in the sample thought to be occurred after stirred for 1 min before viscosity measurement. Meanwhile it was not observed in the gel strength measurement. Particle rearrangement normally occurred in the system to promote the formation of new protein strands thus enhancing cohesiveness, connectivity and homogenous porosity, which in turn affect the texture of the gel (Morand et al., 2011). further studies are needed to learn more about the correlation between viscosity and gel strength.

\section{CONCLUSIONS}

The treatment of increasing the $\mathrm{pH}$ of milk in cheese industry produced sweet whey used for the production of denatured whey protein concentrate, with the following properties including decrease in protein content, increase solubility and finer microstructure. The denatured whey protein shows the low ability to hold the water and the tendency to form bonds between protein particles so that the viscosity value increases. The whey protein has a role as a structure controller so the high protein food properties can be adjusted by adding whey protein produced at different $\mathrm{pH}$ levels.

\section{ACKNOWLEDGMENTS}

This work financially supported by the Directorate General of Higher Education (DGHE) of the Ministry of Education and Culture Republic of Indonesia, under the grant of Penelitian Unggulan Perguruan Tinggi (PUPT) program.

\section{CONFLICT OF INTEREST}

The authors declare that there is no conflict of interest regarding the publication of this paper.

\section{REFERENCES}

Alting, A.C., Weijers, M., de Hoog, E.H.A., van de Pijpekamp, A.M., Cohen Stuart, M.A., Hamer, R.J., de Kruif, C.G., Visschers, R.W. (2004). Acid-induced cold gelation of globular proteins: effects of protein aggregate 
characteristics and disulfide bonding on rheological properties. J. Agric. Food Chem. 52, 623-631. https:// doi.org/10.1021/jf034753r

Andarwulan, N., Kusnandar, F., Herawati, D., (2011). Analisis Pangan. Dian Rakyat, Jakarta.

Anema, S.G., Li, Y., (2003). Effect of pH on the Association of Denatured Whey Proteins with Casein Micelles in Heated Reconstituted Skim Milk. J. Agric. Food Chem. 51, 16401646. https://doi.org/10.1021/jf025673a

Andoyo, R., Guyomarc'h, F., Cauty, C., Famelart, M.-H., (2014). Model mixtures evidence the respective roles of whey protein particles and casein micelles during acid gelation. Food Hydrocolloids Complete, 203-212. https://doi. org/10.1016/j.foodhyd.2013.10.019

Andoyo, R., Lestari, V.D., Mardawati, E and Nurhadi, B. Fractal Dimension Analysis of Texture Formation of Whey Protein-Based Foods. (2018). International Journal of Food Science. Vol 2018, 1-17.

Awwaly, K.U.A., A., M., E., W., (2010). Pembuatan Edible Film Protein Whey: Kajian Rasio Protein dan Gliserol Terhadap Sifat Fisik dan Kimia. Jurnal IImu dan Teknologi Hasil Ternak 5, 45-46.

Awwaly, K.U.A., Mustakim, R.A., B., (2008). Karakterisasi Ekstrak Kasar Enzim Renin Mucor pusillus Terhadap Lingkungan. Jurnal IImu dan Teknologi Hasil Ternak Vol. 3, No. 2 (2008): 1-7.

Bourne, M.C., (2002). Food texture and viscosity: concept and measurement, 2nd ed. ed, Food science and technology international series. Academic Press, San Diego.

Chandan, R.C., A., K., N.P., S., (2008). Dairy Processing and Quality Assurance. Jhon Wiley and Son, New York.

C. I. Onwulata and P. J. Huth. (2018). Whey Processing, Functionality and Health Benefits, Wiley-Blackwell, Oxford, UK.

Dissayanake, M., (2011). Modulation of functional properties of whey proteins by microparticulation. (Dissertation). Faculty of Health, Engineering and Science. Victoria University, Australia.

Donato L, Dalgleish DG (2006) Effect of pH of heating on the qualitative and quantitative compositions of the sera of reconstituted skim milks and on the mechanisms of formation of soluble aggregates. J Agric Food Chem 54:7804-7811

Guyomarc'h, F., Famelart, M.-H., Henry, G., Gulzar, M., Leonil, J., Hamon, P., Bouhallab, S., Croguennec, T., (2014). Current ways to modify the structure of whey proteins for specific functionalities-a review. Dairy Science \& Technology 95. https://doi.org/10.1007/s13594-0140190-5

Hart, H., Hart, D.J., Craine, L.E., (2003). Kimia Organik, Suatu Kuliah Singkat. Erlangga, Jakarta.
Ju, Z.Y., Kilara, A., 1998. Textural Properties of Cold-set Gels Induced from Heat-denatured Whey Protein Isolates. Journal Food Science 63, 288-292.

Lucey, J. A. (2004). Cultured dairy products: an overview of their gelation and texture properties. International Journal of Dairy Technology. Vol 57, No 2/3.

McSweeney, P.L.H., O'Mahony, J.A. (Eds), (2016). Advanced Dairy Chemistry. Springer, New York, USA.

Morand, M., Guyomarc'h, F and Famelart, M-H. (2011). How to tailor heat-induced whey protein/K-casein complexes as a means to investigate the acid gelation of milk-a review. Dairy Science and Technology. Vol. 91. Page 97126.

Pelegrine, D.H.G., Gasparetto, C.A., (2005). Whey proteins solubility as function of temperature and $\mathrm{pH}$. LWT Food Science and Technology 1, 77-80. https://doi. org/10.1016/j.Iwt.2004.03.013

Purnama, S., (2016). Sifat Fungsional Whey Protein Powder yang Diproduksi pada Beberapa Konsentrasi Mineral (Skripsi). Departemen Teknologi Industri Pangan. Fakultas Teknologi Industri PertanianUniversitas Padjadjaran, Bandung

S Khairunnisa, R Andoyo, H Marta and G L U Saripudin. (2018). Process optimization of emergency food originated from denatured whey protein concentrate and dried sweet potato puree. IOP Conf. Series: Earth and Environmental Science. Vol. 157 (2018) 012032

Saleh, E., (2004). Dasar Pengolahan Susu dan Hasil Ikutan Ternak (Skripsi). Program Studi Produksi Ternak, Fakultas Pertanian, Universitas Sumatera Utara, Medan.

Sitindaon A. (2017). Produksi dan Kajian Sifat Fisikokimia Whey Protein Concentrate pada Beberapa Waktu Pemanasan. (Skripsi). Departemen Teknologi Industri Pangan. Fakultas Teknologi Industri Pertanian Universitas Padjadjaran, Bandung.

Situmorang, L., (2016). Sifat Fungsional Bubuk Whey Protein Hasil Pemanasan pada Lama yang Berbeda (Skripsi). Departemen Teknologi Industri Pangan. Fakultas Teknologi Industri Pertanian Universitas Padjadjaran, Bandung.

Smith, K., (2008). Dried Dairy Ingredients. Wisconsin Center for Dairy Research, Madison.

Susanto, T., Yuwono, (2001). Pengujian Fisik Pangan. Unesa University Press, Surabaya.

Walstra, P., Wouters, J.T.., Geurts, T.J., (2006). Dairy science and technology, 2nd ed. ed, Food science and technology. CRC/Taylor \& Francis, Boca Raton.

Winarno, F.G., (1992). Kimia Pangan dan Gizi. PT Gramedia Pustaka Utama, Jakarta. 